\title{
Foucault and Ethical Subjectivity
}

Wendyl M. Luna

$\mathrm{O}$ ne striking discovery of Michel Foucault's Archaeology of Modernity is that no morality is formulated in modernity. Modernity thinks so much of the unthought that it fails to address the ethical question of how one is to live well. ${ }^{1}$ Thinking the unthought is constitutive of "modern morality," which is not morality at all. ${ }^{2}$ If morality is nothing but the effort to answer how one is to live well, then, modernity fails to address this moral, ethical question.

When "man"3 emerges as the positive figure in the field of knowledge, modern thought needs to grapple with those dim, yet positive forces that motivate action. "What is essential [to modern episteme] is that thought, both for itself and in the density of its workings, should be both knowledge and a modification of what it knows, reflection and a transformation of the mode of being of that on which it reflects." 4

${ }^{1}$ In its effort to conceive man, modernity, Foucault opines, reflects on the duality of the cogito and the unthought which characterizes man's mode of being; hence, in Foucault's own neologism, the "cogito-unthought duality." This duality is an expression of the basic reality of man both as an experiencing subject and the never-fully-understood or often-misunderstood object of that experience. By understanding human consciousness as inextricably linked to the unthought, modernity is "a form of reflection...that involves, for the first time, man's being in that dimension where thought addresses the unthought and articulates itself upon it." Michel Foucault, The Order of Things: An Archaeology of the Human Sciences (New York: Vintage Books, 1994), 325.

2 Traditionally, morality consists of two aspects: "moral code" and "morality of behaviors." While morality as "moral code" refers to a prescriptive ensemble of values or rules of action, "morality of behaviors" refers to the real behavior of individuals with respect to the rules and values recommended to them. Foucault says that there is more to Morality than this. He identifies another form that complements the traditional form of morality. This is Foucault's "ethics," the rapport á soi. The kind of relationship one ought to have with oneself, "ethics" determines how the individual is supposed to constitute himself as a moral subject of his own actions. Michel Foucault, "On the Genealogy of Ethics: An Overview of the Work in Progress," in Ethics, Subjectivity and Truth, volume 1 of The Essential Works of Foucault, 1954-1984, ed. by Paul Rabinow, trans. Robert Hurley et al (New York: The New Press, 1997), 263.

3 Foucault identifies "man" as the lacuna characteristic of Modernity. He claims: "Before the end of the eighteenth century, man did not exist." Foucault, The Order of Things, 308. With this statement, Foucault does not mean that no human being as a biological species existed before the nineteenth century. Foucault is not stupid to say that. Foucault's "man" is not simply the two-legged creature who has brains for articulating speech and abstract reasoning. Gutting explains that "man" is used by Foucault to refer to human beings precisely as those individuals for whom representations exist. Gary Gutting, Michel Foucault's Archaeology of Scientific Reason (Cambridge: Cambridge University Press, 1993), 198.

${ }^{4}$ Foucault, The Order of Things, 327. 
It is impossible for modernity to formulate any kind of morality, Foucault claims. Modernity cannot propose a morality not because it is pure speculation but because it is a mode of action: "[Modern thought] is reflection, the act of consciousness, the elucidation of what is silent, language restored to what is mute, the illumination of the element of darkness that cuts man off from himself, the reanimation of the inert." ${ }^{5}$ Not only is modern thought a mode of action, it also is a perilous action: "As soon as [thought] functions it offends or reconciles, attracts or repels, breaks, dissociates, unites or reunites; it cannot help but liberate and enslave." 6

The Kantian Categorical Imperative is an instance of an absence of morality. Foucault explains: "The Kantian moment...is the discovery that the subject, in so far as he is reasonable, applies to himself his own law, which is the universal law." Dreyfus and Rabinow elaborate this point. Recognizing the Sartrean undertone in Foucault's reading of the Kantian Categorical Imperative, they write: "Whoever achieves total clarity about himself and society would, indeed be a sovereign chooser, but a sovereign that no longer had any reasons for his choice." 8 Acting on a maxim that can be universalized is the action of a reasonable subject but it postpones, if not leaves out, "doing good." Action in modern times is ontologically prior to anything. The act of reflecting on the "cogito-unthought" duality so preoccupies modernity that it fails to be anything other than this reflective act, suspending, therefore, any ethical act.

The absence of morality in Modernity prompted Foucault to do an excursion into Greek culture and thought. He explains: "If I was interested in Antiquity it was because...the idea of a morality as obedience to a code of rules is now disappearing, has already disappeared." That moderns trust and believe so much in "man" and that we find it hard to think differently from the modern way of thinking, we have lost the moral sense. The search for "aesthetics of existence" is Foucault's response to the absence of morality. ${ }^{10}$

\section{The "Aesthetics of Existence"}

In Greek ethics people were concerned with their moral conduct, their ethics, their relations to themselves and to others... what they were worried about, their theme was

\footnotetext{
${ }^{5}$ Ibid., 328.

${ }^{6} \mathrm{Ibid}$.

${ }^{7}$ Foucault, The Order of Things, footnote no. 2, 343.

${ }^{8}$ Hubert Dreyfus and Paul Rabinow, Foucault: Beyond Structuralism and Hermeneutics, $2^{\text {nd }}$ ed. (Chicago: University of Chicago Press, 1983), 37.

9 Michel Foucault, "An Aesthetics of Existence," in Michel Foucault: Politics, Philosophy, Culture, ed. by Lawrence Kritzman, trans. by Alan Sheridan et al (New York: Routledge, 1990), 49.

${ }^{10}$ Ibid.
} 
to constitute a kind of ethics which was an aesthetics of existence. $^{11}$

If Mona Lisa could be painted beautifully, if the Pieta or the statue of David could be carved perfectly, if the music of the Baroque, Classical and Romantic periods could be appreciated well, and if Oscar-winning films were good forms of entertainment, why couldn't one's life be lived aesthetically? Living a beautiful life was what the Hellenistic and Roman world offered for us people of today. We can learn from the Greco-Roman citizens how to live such a life.

Ancient Greeks were concerned with constituting a beautiful, aesthetic life out of their own lives more than anything. To them, ethics was not so much about following the norms their society imposed on them thereby pleasing other members in the society and was not so much about following religious orders in order to please their gods; rather, ethics was mainly about one's choice to live a beautiful life. ${ }^{12}$

We ask the question: What makes the "aesthetics of existence" beautiful?13 What makes this existence moral? As a response to the first question, Foucault writes: The "aesthetics of existence" "took on the brilliance of a beauty that was revealed to those able to behold it or keep its memory present in mind." 14 The "aesthetic of existence" is a beautiful thing esteemed as beautiful by a beholder such that we can say that the beauty of this existence is said to be "in the eyes of the beholder." It is the beholder who appreciates this beautiful existence precisely as beautiful.

However, this beholder is only there to appreciate this beautiful existence and is not the one who constitutes it as beautiful. For, this aesthetic existence is objectively beautiful. Like any other beautiful things, the "aesthetics of existence," taking on the brilliance of a beauty, is an instance of "Beauty." There is an objectivity to the beauty of the "aesthetics of existence" and this is what the beholder beholds. The "beauty" of this existence, its "aesthetic" effect, lies in its moral worth.

O'Leary elaborates this point. He asks what is "aesthetic" about the "aesthetics of existence." Casting doubt on Foucault's understanding of the two key terms in Greek thought, techne as "art" and kalon as "beautiful,"

\footnotetext{
${ }^{11}$ Foucault, "On the Genealogy of Ethics: An Overview of Work in Progress,” 255.

12 Commentators distinguish between the two senses of ethics that are at play in Foucault's work. Deleuze writes: “The key thing, for Foucault, is that subjectification isn't to do with morality, with any moral code: it's ethical and aesthetic, as opposed to morality, which partakes of knowledge and power." Gilles Deleuze, Negotiations 1972-1990 (New York: Columbia University Press, 1995), $114 . \quad$ Likewise, according to Raymond Geuss, there is a difference between ethics as a set of moral codes and ethics as a ways of seeing the world. See Outside Ethics (New Jersey: Princeton University Press, 2005).

${ }^{13}$ For a discussion of Foucault's "aesthetics of existence," see Neil Levy's "Ethics and Rules: A Political Reading of Foucault's Aesthethics of Existence," in Philosophy Today, 42:1 (Spring 1998), 79-84.

${ }_{14}$ Michel Foucault, The Use of Pleasure, volume 2 of The History of Sexuality, trans. by Robert Hurley (New York: Pantheon Books, 1985), 89.
} 
O'Leary investigates how some ancient Greek philosophers understood and used these terms. Plato considers techne or "craft" as analogous to the practice of virtue; to him, courage is a skill or craft similar to medicine. Aristotle's good man is one who is able to hit the mean; he is like a shoemaker who makes the neatest or the best shoe out of the supplied leather. Epictetus compares himself to a craftsman who molds his students. What is central in Hellenistic thought, O'Leary argues, is the idea that virtue is a "techne tou biou," which can be literally translated as "skill in living," or poetically described as "aesthetics of existence." Here is O'Leary: "The conceptualization of the good man as he who knows his 'materials'... and as he who possesses the skill required to put his life together in such a way that it will bring its 'craftsman' both happiness and prosperity." 15 In Greek thought, the ideas of the good and the beautiful collapse onto each other. This collapse is what Foucault exploits with his translation and understanding of "techne tou biou" as "aesthetics of existence."

The person who creates himself as a work of art is one who fashions or molds himself to be a virtuous man. A beautiful man is one who is a good man. This leads us to our second question: What makes the "aesthetics of existence" ethical? Explaining the moral value this "aesthetics of existence" has, Foucault writes: "An 'aesthetics of existence' is a way of life whose moral value [depends] on certain formal principles certain formal principles in the use of pleasures, in the way one distributed them, in the limits one observed, in the hierarchy one respected." 16 In another passage, he writes: "The will to be a moral subject and the search for an ethics of existence were...mainly an attempt to affirm one's liberty and to give one's own life a certain form." 17 Living a beautiful, ethical existence is to "stylize" or give form to one's self.

One way of stylizing oneself is by practicing temperance. If one were to live a beautiful life, s/he has to hit the "golden mean." Foucault quotes some passages from the works of Plato to give us a glimpse of this moderate, aesthetic existence. Plato writes in Gorgias: "The soul which has order is orderly? Of course it is. And the orderly soul is temperate? It certainly must be. Then the temperate soul is good...And if they are true, then apparently the man who wants to be happy must pursue and practice temperance." 18 In the Republic, Plato writes: "When a man's soul has a beautiful character, and his body matches it in beauty and is thus in harmony with it, that harmonizing combination...is the most beautiful spectacle for anyone who has eyes to see...the right kind of love is to love a well-behaved and beautiful person with moderation and restraint." 19

Temperance, moderation was the virtue characteristic of a true man in the "virile" society of Greek antiquity. If a man were to be truly man, he had to practice moderation with his use of pleasures: "In the use of male pleasures,

15 Timothy O'Leary, Foucault: The Art of Ethics (London and New York: Continuum, 2002), 52.

${ }^{16}$ Foucault, The Use of Pleasure, 89.

17 Foucault, "An Aesthetics of Existence," 49.

18 Plato, Gorgias, 506d-507d; as quoted by Foucault in The Use of Pleasure, 90.

19 Plato, Republic, 402d-403b; as quoted by Foucault in The Use of Pleasure, 90. 
one had to be virile with regard to oneself, just as one was masculine in one's social role. In the full meaning of the word, moderation was a man's virtue."20 A man was said to be virile and strong if he was able to conquer and tame his own desires, if he was able to practice moderation with the use of his desires. Moderation characterized manhood and virility for the ancient Greeks.

Moderation, apart from characterizing manhood, also determined whether a man had mastery, dominion over himself. To be a master of oneself was necessary before one could exercise dominion over others. If a man were not a master of himself, he could not be a strong and true man. Moreover, he could not be an effective father to his children, a good husband to his wife, and a good, active partner with his boy. We can see here that the "aesthetics of existence" is an ethics that is not egotistic or narcissistic; for, after governing oneself well, it then seeks to govern others well. It has, should have, a political dimension. It should not remain within the confines of oneself but should go out and reach out to others.

Governing oneself well which eventually enables one to govern others well, exercising moderation with one's use of pleasures, mastering oneself - all this typifies a life that is lived aesthetically, morally. Living an aesthetic existence is primarily a personal choice. If one chooses to live such an existence, one wills to live a beautiful life. Living a beautiful life is living well. Foucault explains: "This elaboration of one's own life as personal work of art...was at the centre... of moral experience, of the will to morality." 21 Choosing to live an aesthetic existence is a personal ethics. Being personal, this ethics can be lived by the ethical subject who constitutes his existence beautifully as he possibly can.

\section{The Ethical Subjectivity of a Greek Boy}

Foucault discusses in The Use of Pleasure three practices by which ancient Greek men sought to "stylize" themselves, i.e., to live the "aesthetics of existence." There is their dietary practice Foucault discusses under "Dietetics." 22 Their practice of domestic government is discussed under "Economics," 23 and their love/sexual relationship with a free-born Greek boy is discussed under "Erotics."24 Dietetics was understood as an art of the everyday relationship of a man with his body; economics was an art of the conduct of man as a head of his family; and, erotics as an art of the conduct of both man and boy in a love/sexual relationship. ${ }^{25}$ We focus ourselves on the last stylization, especially that of the boy's.

A sexual relation between a man and a boy in Greek antiquity, viz., "erotics," was a big problem for the Greeks. It was a big problem for Greek

\footnotetext{
${ }^{20}$ Foucault, The Use of Pleasure, 83.

${ }^{21}$ Foucault, "An Aesthetics of Existence," p. 49.

${ }^{22}$ See Foucault, The Use of Pleasure, 95-139.

${ }^{23}$ Ibid., 141-184.

${ }^{24}$ Ibid., 185-225.

${ }^{25}$ Ibid., 93.
} 
ethics and thought on account of the paradoxical status of the boy. Foucault calls this problem the "antimony of the boy." 26 That a boy has not yet achieved his full manly status, he may be an object of pleasure and may be a prey of men's sexual desires. However, he would soon pass his youth and become a man himself. And so, the ancient Greeks were pre-occupied with the question: To what extent could a boy be an object of pleasure? How can a boy be truly man when at one point of his life he was objectified? How can he be a true master of himself, be a true subject of his pleasures when he once was an object of other's pleasures?

In the domination-submission structure or active-passive structure of Greek antiquity, it was not a problem to be domineering or active or that it was all right for Greek male citizens to be subjects of their pleasures. However, it was unacceptable, deplorable, improper or objectionable for any of them (including would-be men) to be an object of pleasure. It was all right for Greek men to have Greek boys. Mature male citizens, being free and being men themselves, had the freedom to choose from so-called "boy-objects," with whom they engage in a love/sexual relationship.

The status of the Greek boy, however, was a big problem for ancient Greeks. Greek sexual ethics articulates: A boy should never be an object of anybody's pleasures. Here is Foucault: "The relationship that [the boy] was expected to establish with himself in order to become a free man, master of himself and capable of prevailing over others, was at variance with a form of relationship in which he would be an object of pleasure for another."27

The antimony of the boy was for the Greeks more complicated than the status of wives. While the wife, if she is worthy of respect, remains under the exclusive authority of her husband who, being a master of himself and of his household, governs his wife; the boy, on the other hand, constitutes an independent center vis-à-vis his suitors/lovers: "[Erotics] implied self-mastery on the part of the lover; it also implied an ability on the part of the beloved to establish a relation of dominion; and lastly, it implied a relationship between their two moderations, expressed in their deliberate choice of one another." 28

In relation to his suitors, a boy is free and independent. It is his discretion to reject or accept their proposals and no one can influence his decisions. Inasmuch as Greek male citizens had the freedom to choose their Greek boys, Greek boys also had the freedom to choose their male-lovers. He may entertain as many suitors as he possibly can. When he has accepted a suitor to be his lover, however, he is expected to give himself freely to his partner. Foucault writes: "The boy was expected to give, out of kindness and not for his own pleasure, something that his partner sought with a view to the pleasure he would enjoy; but the partner could not rightfully ask for it without a matching offer of presents, services, promises, and commitments that were altogether different in nature from the 'gift' that was made to him."'29

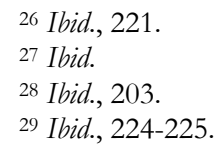


What is at stake in the game of "erotics" is the stylization of both parties: the stylization of the suitor and that of the boy. This stylization is living a beautiful, moral life expected of the lovers engaged in "erotics." Like any other love-relations, "erotics" is a give-and-take relationship. It is two-way. A suitor, if he really likes the boy, is expected to give and show his best so the boy may choose him to be his lover. And if he is chosen by the boy to be his lover, he is expected to give the best of himself. How does a Greek boy stylize himself in "erotics"? He should not be a prostitute. He should not abuse his suitors or beloved. He should be free: free in choosing who his partner will be; free in giving himself to his partner; free in exercising his pleasures; and, free in not engaging in "erotics" anymore, if he ever chooses. If he were to live the "aesthetics of existence," the Greek boy must preserve his honor and must use his pleasures well.

The boy stylizes himself in such a way that he preserves his honor, his eminent worth, which is what is really at stake in the game of "erotics." The boy's honor is related not to his future marriage but to his status, his future place in the society. To preserve his honor and worth, the boy should mind his own conduct and use his pleasures well. If a boy misuses his pleasures, if he misbehaves and dishonors himself during his youth, he is deemed unworthy of governing the affairs of society. Foucault gives a general description of a boy's "misuse" of his pleasures:

It was not good...for a boy to behave 'passively,' to let himself be manipulated and dominated, to yield without resistance, to become an obliging partner in the sensual pleasures of the other, to indulge his whims, and to offer his body to whomever it pleased and however it pleased them, out of weakness, lust, or self-interest. ${ }^{30}$

\section{Conclusion}

In Foucauldian ethics, we are dealing with a person, yes, but, more fundamentally, we are dealing with a person who acts. By dealing with the acting person, we do not just focus ourselves on the person himself, nor on his actions alone. We do not separate the person from his acts. What Foucault tries to resolve in his "ethics" is not only how one constitutes his ethical subjectivity but also why this particular action of a person exists and not any other action. Asking the latter question entails investigation of the relation of this one act to other acts done by the person we are dealing with. A person's act becomes a "text" that the archaeological method diagnoses.

There is no universal way as to how one could constitute one's ethical subjectivity. There are as many ways of constituting ethical subjectivity as there are individual persons. The "aesthetics of existence" is unique to every individual who chooses to live a beautiful existence. There is no universality

${ }^{30}$ Ibid., 211. 


\section{ETHICAL SUBJECTIVITY}

with the "aesthetics of existence." Or, the universality of this beautiful existence is its very particularity or individuality in every ethical subject. No one can impose one's ethical subjectivity onto another person. What one can do best is offer one's ethical subjectivity as a sample-subjectivity which other persons may accept or reject.

It is not a matter of determining which subjectivity is the best, better or worse than the other. The ethical subjectivities of the ancient Greeks are not better or worse subjectivities than, say, modern or Christian subjectivities. Every subjectivity is the best, which is the same as saying, no subjectivity is the best. One's subjectivity may be the best for oneself but it may not be good for others.

What matters is one person constituting his or her own ethical subjectivity with respect to one's customs and traditions, the norms and values one's society upholds, one's religious beliefs and convictions, and many other factors. The ethical subject could constitute his or her ethical subjectivity, s/he could live a beautiful existence, $\mathrm{s} /$ he could create a work of art out of his or her life, if and when s/he considers the ethos of his society. To wit, with respect to moral practices, ethical subjectivity may be constituted.

The Graduate School, University of Santo Tomas, Philippines

\section{References}

Deleuze, Gilles, Negotiations 1972-1990 (New York: Columbia University Press, 1995).

Dreyfus, Hubert and Rabinow, Paul, Foucault: Beyond Structuralism and Hermeneutics, $2^{\text {nd }}$ ed. (Chicago: University of Chicago Press, 1983).

Foucault, Michel, "On the Genealogy of Ethics: An Overview of the Work in Progress," in Ethics, Subjectivity and Truth. Volume 1 of The Essential Works of Foucault, 1954-1984, ed. by Paul Rabinow, trans. by Robert Hurley et al. (New York: The New Press, 1997).

, The Order of Things: An Archaeology of the Human Sciences (New York: Vintage Books, 1994).

"An Aesthetics of Existence," in Michel Foucault: Politics,

Philosophy, Culture, ed. by Lawrence Kritzman, trans. by Alan Sheridan et al. (New York/London: Routledge, 1990). , The Use of Pleasure, Volume 2 of The History of Sexuality, trans. by

Robert Hurley (New York: Pantheon Books, 1985).

Geuss, Raymond, Outside Ethics (New Jersey: Princeton University Press, 2005).

Gutting, Gary, Michel Foucault's Archaeology of Scientific Reason (Cambridge: Cambridge University Press, 1993).

Levy, Neil, "Ethics and Rules: A Political Reading of Foucault's Aesthethics of Existence," in Philosopby Today, 42:1 (Spring 1998).

O'Leary, Timothy, Foucault: The Art of Ethics (London and New York: Continuum, 2002). 